\title{
ISSUES OF CLIMATIC AND GEOGRAPHICAL ADAPTATION OF ATHLETES
}

\author{
Samoilov AS, Petrova W凶
}

Russian State Research Center — Burnasyan Federal Medical Biophysical Center of Federal Medical Biological Agency, Moscow, Russia

The problem of optimizing the functional state of an athlete, who often travels to the training venues and competition sites, is an integral part of the system for ensuring the maximum efficiency of his professional activity. An athlete, who lives and trains in central Russia, the next day may find himself at the competition halfway around the world, in any climatic zone or time zone. This review details the stages and terms of the adaptation of athletes; criteria of the athlete's adaptation to the new climatic conditions and geographical settings are provided. The existing adaptation models are presented, together with the recommended method for diagnosis and control of climatic and geographic adaptation in athletes.

Keywords: climatic and geographical adaptation, jetlag, professional athletes, pharmacological support, physiotherapy

Author contribution: Samoilov AS — study concept, final editing; Petrova W — raw data analysis, manuscript writing and editing.

$\triangle$ Correspondence should be addressed: Victoria V. Petrova

Rogova, 18, Moscow, 123098, Russia; sportvrach@outlook.com

Received: 10.12.2021 Accepted: 20.12.2021 Published online: 22.12.2021

DOI: $10.47183 /$ mes.2021.046

\section{ПРОБЛЕМЫ КЛИМАТОГЕОГРАФИЧЕСКОЙ АДАПТАЦИИ СПОРТСМЕНОВ}

А. С. Самойлов, В. В. Петрова

Государственный научный центр Российской Федерации - Федеральный медико-биофизический центр имени А. И. Бурназяна, Москва, Россия

Проблема оптимизации функционального состояния спортсмена при частых переездах в места тренировок и проведения соревнований является неотьемлемым звеном системы обеспечения максимальной результативности его профессиональной деятельности. Спортсмен, живущий и тренирующийся в средней полосе России, на следующий день может оказаться на соревнованиях в другом полушарии Земли в любой климатической зоне и любом часовом поясе. В обзоре детально рассмотрены этапы и сроки адаптации спортсменов, приведены критерии адаптированности спортсмена к новым климатогеографическим уловиям. Представлены существующие модели адаптации и рекомендуемая методика диагностики и контроля климатогеографической адаптации у спортсменов.

Ключевые слова: климатогеографическая адаптация, десинхроноз, профессиональные спортсмены, фармакологическая коррекция, физиотерапия Вклад авторов: А. С. Самойлов - концепция, финальное редактирование; В. В. Петрова - анализ исходных материалов, написание текста, редактирование статьи.

$\triangle$ Для корреспонденции: Виктория Викторовна Петрова

ул. Рогова, д. 18, г. Москва, 123098, Россия; sportvrach@outlook.com

Статья получена: 10.12.2021 Статья принята к печати: 20.12.2021 Опубликована онлайн: 22.12.2021

DOI: $10.47183 /$ mes.2021.046

International competitions, such as the Olympic Games or the World Cups, are conducted anywhere on the globe. That is why the issues of the athletes' adaptation are the pressing issues of the sports medicine, which in turn determine the relevance of the physiological and hygienic substantiation for optimization of the athletes' adaptation both to the climatic conditions and to the jet lag.

The issues of the athletes' adaptation to the changing climatic conditions and geographical settings were studied by many eminent specialists in sports medicine. Their papers present theoretical aspects of the effects of the climate loads and the mechanisms, underlying adaptation to the changing environmental conditions, provide a list of various groups of remedies (pedagogical, hygienic, biomedical, and psychological). However, no specific schemes for their use by athletes during the acclimatization period are reported.

\section{Adaptation phases and terms}

Adaptive responses of the human body may be roughly divided into three groups:

a) general adaptive physiological responses related to the basic functions, which make it possible to live and work in changing environment;

b) specific morphofunctional, physiological, and psychological changes based on the genotype-phenotype features; c) adaptative behavioral responses (water drinking schedule, diet, clothing, and the facilities equipped with air conditioning or heating systems) [1].

Based on the above classification, we believe that behavioral aspects of adaptation are of particular importance, since their realization is up to the athlete, and these aspects contribute greatly to the success of both general physiological responses and specific responses to the changing environment.

The period of the athlete's body acclimatization (adaptive reorganization) may vary considerably. The period and nature of the acclimatization response are influenced by both environmental factors (contrasting climate zones change, daily and seasonal changes in weather patterns) and the athlete's condition (individual characteristics, age, acute and chronic disorders, state of the central nervous system, respiratory system, and other systems, weather sensitivity, etc.) [2].

Adaptive capacity of the body (adaptivity, plasticity of regulatory systems) enables the athlete to adjust to a changing environment within a short time.

High levels of physical performance increase the body's capability of adaptation to environmental factors. This is because physical exercise improves cardiovascular health (in particular, heart rate is lowered, stroke volume and cardiac output are increased, etc.) [3].

Sufficient mental capacity makes it possible to successfully endure the exposure to environmental factors. Emotional management skills allow one to ensure the individual's optimal activity and adaptation to the changing environment. 
The contrasting changes in climatic conditions and geographical settings determine the physiological loads the body is exposed to, i.e. the intensity of the body's mechanisms of adaptation, related to the impact of the climate change. The more contrasting are the climate changes, the larger is the amount of information brought by the climate change, the more severe is the stress to adaptive mechanisms, and the higher is the risk of adverse effects during acclimatization (disadaptation). Travel speed when changing the climatic conditions has a certain impact [4].

The main risk factors for disadaptation in athletes are as follows: history of injuries, acute disorders, and the extent to which the chronic disorder is compensated.

The following factors and types of reserve contribute to the body's adaptive capacity: biological reserve (genetically determined), professional training, biochemical reserve.

The majority of adaptive responses occur in two phases: initial adaptation (short-term, imperfective) and subsequent adaptation with the formation of structural trace (long-term, perfective) [5].

The adaptive response short-term phase starts immediately after exposure to the stimulus and could be realized based on the previously shaped physiological mechanisms only. The long-term phase of adaptation develops gradually with the prolonged or repeated exposure to environmental factors [6].

A the same time, a thorough approach to the athlete's condition assessment during the acclimatization period shows that the period from days 1-3 to days 7-8 after the journey is the worst (Fig. 1) [7].

During the first three days after the journey, the "stress cap" is developed in the athlete being pressurized by the changes in climatic conditions and geographical settings, high social responsibility, psycho-emotional stress, and competition loads. During this period, the athlete demonstrates the emotional uplift, accompanied by the stress hormones release and the body functional reserve mobilization. Regardless of the numerous literary sources suggesting the opposite, any environmental stimuli, including the competitive activity, are well tolerated during this period.

Since day 7-8 of exposure to a new environment, the athlete enters the phase of developing the long-term adaptation (structural trace). During this period, the body's resistance is close to baseline, and subsequently the functional reserve capacity is increased.

From day 3 to day 7 , within the period between "taking off the stress cap" and the beginning of the structural trace formation, the athlete's body becomes the most vulnerable. During this period, the risk of the reduced athlete's resistance to environmental factors is the most probable.

The discussed adaptation phases suggest that the option of performing within the first three days after the journey to the competition venue (the phase characterized by the development of "stress cap") is most appropriate for sports where the competitions are carried out for 1-3 days. In our opinion, in case of performance on day 4 of adaptation or later, it is advisable to focus on addressing the combination of bio-psycho-social issues, which determines both successfual adaptation and successful competitive activity. For more details, see below.

\section{Criteria for athlete's adaptation to new climatic conditions and geographical settings}

The criteria for the athlete's body adaptation are roughly divided into non-specific (integral) and specific (Fig. 2). The non-specific criteria reflect the athlete's body functional state when exposed to any factor; specific criteria reflect the typical alterations evolving under the influence of one or another damaging factor [8].

In case of favorable adaptation, there are minor deviations of the non-specific and specific indicators, which finally equate the normative values, typical for the population in a certain location. This state is regarded to as the "person's environmental portrait" [9].

Acceleration or facilitation (optimization) of adaptation to the changing environment is one of the ways to improve the efficiency of the athlete's competitive activity. Optimization of the adaptation processes results in the improved overall athlete's body resistance and body defences, as well as in the reduced impact of the disease pathogenic mechanisms, and in mitigating the lack of external (natural) stimuli.

In order to define the criteria for the adaptive capabilities and the integrated assessment of the athlete's body functional reserve capacity, the following formula was developed:

$$
\mathrm{BAC}=\frac{\mathrm{PP} \times \mathrm{HT} \times \mathrm{PT} \times \mathrm{MC}}{\mathrm{HI} \times \mathrm{ChD} \times \Delta \mathrm{CCC} \times \mathrm{TZ} \times \mathrm{V}_{\mathrm{tr}}},
$$

where BAC - body's adaptive capacity (adaptivity, plasticity); PP - physical performance; HT — heat tolerance; PT professional training; $\mathrm{MC}$ - mental capacity; $\mathrm{HI}$ - history of injuries; $\mathrm{ChD}$ - chronic disorders; $\triangle \mathrm{CCC}$ - contrast between

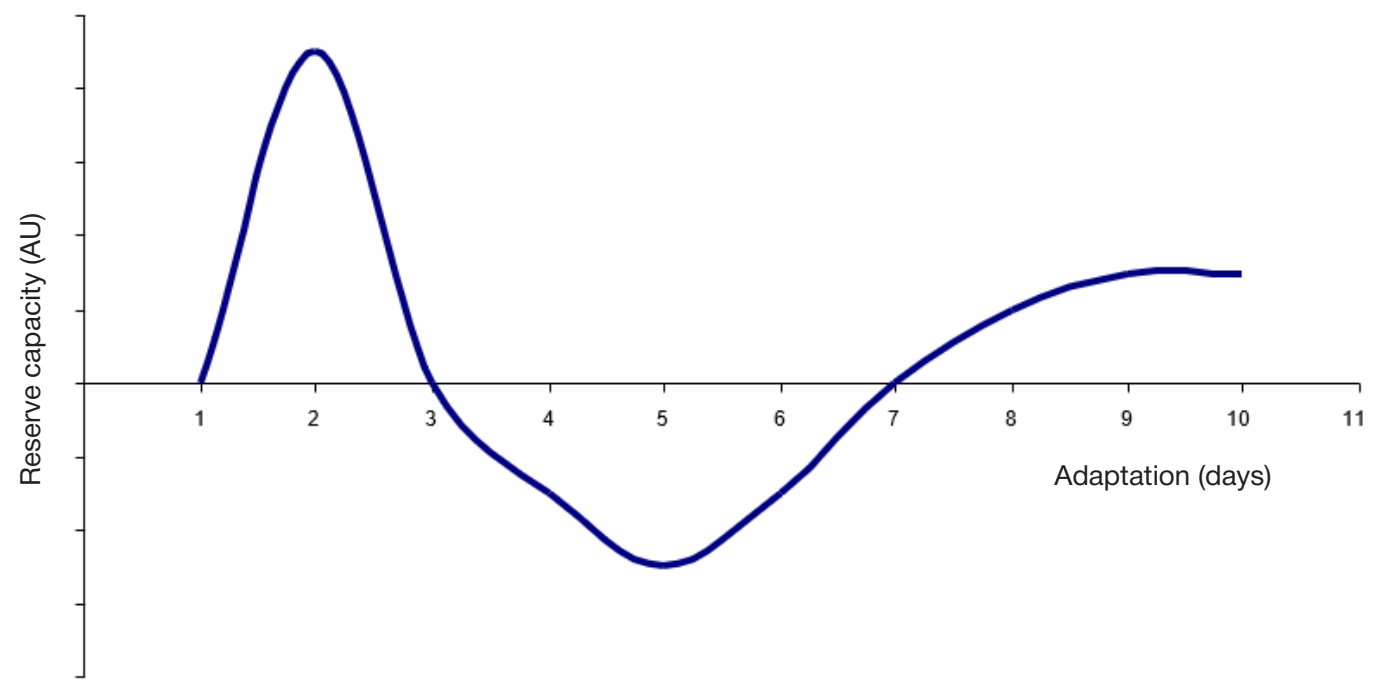

Fig. 1. Dynamic changes in body's reserve capacity when exposed to environmental factors [7] 


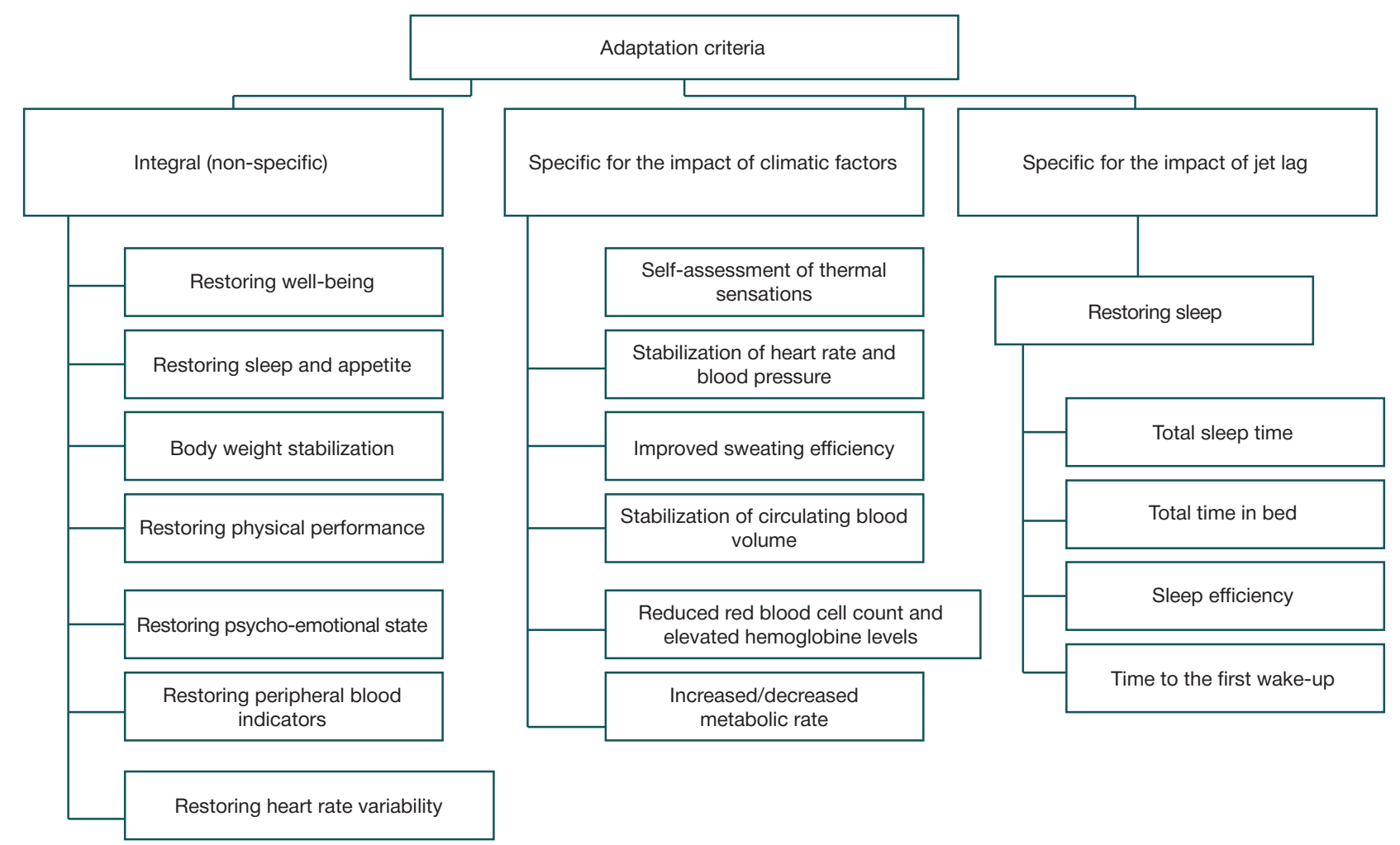

Fig. 2. Criteria for adaptation to hot climate

climatic conditions; TZ — number of time zones crossed; $\mathrm{V}_{\mathrm{tr}}$ athlete's speed of travel.

The closer to one is the BAC value, the larger is the athlete's adaptive capacity and the higher is his functional readiness.

The groups of individuals with four types of response are distinguished based on their functional systems' response to the changing environment. The first type consists of individuals unable to adapt to the changing environmental conditions; such individuals constitute only $5-7 \%$, i.e. this group is the smallest one.

The second, "flexible", type constitutes $20-30 \%$ of the population. It consists of individuals with the pronounced deviations of homeostatic indicators (heart rate, blood pressure, $\mathrm{T}^{\circ} \mathrm{C}$, etc.) due to exposure to environmental factors, and the rapid recovery of the body's functional state after the end of exposure. These individuals are characterized by high quality performance in the changing environment along with the pronounced cardiorespiratory response and the lack of thermal stability.

The third, "passive", type constitutes $20-30 \%$ of the population. This group demonstrates stable homeostasis (stabilization) of the adjustable parameters when exposed to the factor, and the prominent deviation of the parameter after the end of exposure. The athletes in this group are characterized by decreased performance and inactive decision-making style before adjusting to the changed climatic conditions.

The fourth, "mixed", type constitutes about 40\%. This type integrates the features of responses typical for individuals of the second and third types, as well as of the types with the modest predominance of one of those. Such individuals have a stable, albeit slightly decreased, level of maintaining their functional state and performance when operating in the changed environment.

Apart from the individuals not capable of the climate change adaptation, the listed above three types of response to environmental stimuli are divided in literature into the following types: hyperergic-normoergic-hypoergic types, or sprintermixed-stayer. Individuals of the "mixed" type are considered normoergic [10].

The athetes with hyperergic type of response are able to compete since the first day after their arrival in the different climate zone. However, it should be pointed out that their performance would be at the expense of the enormous physiological loads.

The athetes with hypoergic type of response have a poor prognosis of performing after changing the climate zone. They need to be adapted to the environment, in which they have to perform, for a long period.

Thus, after defining the type of the athlete's body response, we can assume the athlete's individual response to the changed climatic conditions, and plan the biomedical support activities.

\section{Rationale for the models of the Russian national team athletes' adaptation to the new climatic conditions and geographical settings}

In view of the foregoing, we have proposed seven models of adaptation to climate for the athletes performing in the open areas. The essence of the model, the summary, the sports a model is relevant for, and the time frame are presented in Table 1.

In our opinion, the model of "readaptation" is the more preferable one among the listed above models. In this case, the athlete's adaptation to climatic loads is formed naturally during the repeated appearances on the competitions, carried out in various climatic conditions and time zones. Readaptation is accompanied by the formation of "vegetative memory", triggering the sequence of adaptive responses, which, consequently, reduces the adaptation time. This model is appropriate for athletes from all sports.

The option of "no need for adaptation" is the most appropriate for sports, where the competitions last for 1-2 days [11]. During the first three days after arrival, the athlete 
Table 1. Models and strategies of adaptation for the highly qualified athletes performing in the open areas

\begin{tabular}{|c|c|c|c|c|}
\hline \multirow[t]{2}{*}{ Adaptation model } & \multicolumn{4}{|c|}{ Adaptation strategy } \\
\hline & $\begin{array}{l}\text { Days between arrival and } \\
\text { the start of competition }\end{array}$ & Essence of strategy & Summary & Sports the model is relevant for \\
\hline $\begin{array}{l}\text { 1. No need for } \\
\text { adaptation }\end{array}$ & $1-2$ days & "Stress cap" & $\begin{array}{l}\text { Emotional tension and the new } \\
\text { environment cause the release } \\
\text { of stress hormones and body } \\
\text { functional reserve mobilization }\end{array}$ & $\begin{array}{l}\text { Short-term competitions } \\
\text { (sprint, all types of jumping, } \\
\text { throwing, etc.) }\end{array}$ \\
\hline $\begin{array}{l}\text { 2. Long-term } \\
\text { adaptation }\end{array}$ & 10-14 days & $\begin{array}{l}\text { The long-term adaptation } \\
\text { structural trace formation by } \\
\text { day } 10-14\end{array}$ & $\begin{array}{c}\text { Capacity of all specific } \\
\text { adaptation systems is increased }\end{array}$ & $\begin{array}{l}\text { Long-term activities (marathon, } \\
\text { bicycle racing, triathlon, etc.), and } \\
\text { sports where the competitions } \\
\text { are carried out for a few days } \\
\text { (football, beach volleyball, etc.) }\end{array}$ \\
\hline $\begin{array}{l}\text { 3. Preliminary } \\
\text { adaptation } \\
\text { (preconditioning) }\end{array}$ & $\begin{array}{l}10-14 \text { days } \\
\text { (up to } 21 \text { days) }\end{array}$ & $\begin{array}{l}\text { Preliminary adaptation in } \\
\text { places with a similar climate } \\
\text { within the same time zone }\end{array}$ & $\begin{array}{l}\text { Long-term adaptation is formed. } \\
\text { Readaptation is required after } \\
\text { arrival to the competition venue }\end{array}$ & $\begin{array}{l}\text { Long-term activities (marathon, } \\
\text { bicycle racing, triathlon, etc.), and } \\
\text { sports where the competitions } \\
\text { are carried out for a few days } \\
\text { (football, beach volleyball, etc.) }\end{array}$ \\
\hline 4. Readaptation & $1-2$ days & $\begin{array}{l}\text { Multiple appearances of the } \\
\text { athlete on the competitions } \\
\text { carried out in the same } \\
\text { climatic conditions within the } \\
\text { same time zone }\end{array}$ & $\begin{array}{l}\text { "Vegetative memory" is formed, } \\
\text { triggering the sequence of } \\
\text { adaptive responses. This } \\
\text { occurs in a natural way when } \\
\text { the athlete takes part in various } \\
\text { competitions }\end{array}$ & All sports \\
\hline 5. Cross-adaptation & $10-14$ days & $\begin{array}{l}\text { Adaptation to one factor } \\
\text { improves adaptation to } \\
\text { another factor }\end{array}$ & $\begin{array}{l}\text { Hypoxic hypoxia demonstrates } \\
\text { the broadest range of } \\
\text { cross-adaptation }\end{array}$ & $\begin{array}{l}\text { All sports (especially those that } \\
\text { require physical endurance) }\end{array}$ \\
\hline $\begin{array}{l}\text { 6. Engineered } \\
\text { adaptation with the } \\
\text { use of technical } \\
\text { means }\end{array}$ & $5-7$ days & $\begin{array}{l}\text { Simulation of the conditions } \\
\text { for adaptation, (Environmental } \\
\text { chambers, equipment for } \\
\text { artificially induced } \\
\text { hypoxia, etc.) }\end{array}$ & $\begin{array}{l}\text { Arises from the body's non- } \\
\text { specific response to the effects } \\
\text { of various environmental factors, } \\
\text { the body has to adjust to }\end{array}$ & All sports \\
\hline $\begin{array}{l}\text { 7. Preliminary self- } \\
\text { adaptation }\end{array}$ & 5-7 days & $\begin{array}{l}\text { Applying the simple } \\
\text { techniques to boost the } \\
\text { reserve capacity of the body } \\
\text { (cold exposure training, } \\
\text { sauna, contrast bath } \\
\text { therapy, etc.) }\end{array}$ & $\begin{array}{l}\text { Partial adaptation in response } \\
\text { to the exposure to various } \\
\text { environmental factors }\end{array}$ & All sports \\
\hline
\end{tabular}

demonstrates the emotional uplift, accompanied by the stress hormones release and the body functional reserve mobilization, i.e. the "stress cap" is being formed [12].

The models of "cross-adaptation" and "preliminary selfadaptation" may be used in athletes from all sports. It should be noted that hypoxic hypoxia demonstrates the broadest range of cross-adaptation, and is the most appropriate for the representatives of cyclic sports. Cross-adaptation is based on the fact that adaptation to one factor improves adaptation to another factor.

It is assumed that preliminary self-adaptation involves the use of simple techniques for boosting the reserve capacity of the body by the athlete (cold exposure training, sauna, contrast bath therapy, etc.).

In our opinion, the use of the "long-term", "preliminary" and "engineered" adaptation in athletes is socially and economically unreasonable.

When using the selected stratedy, and in order to correctly assess the integral adaptation criteria, it is recommended to analyze the pooled data, obtained with the use of the following generally accepted methods:

- supervision of the sport physician or coach;

- heart rate variability;

- WAM questionnaire (Well-being, Activity, Mood);

- daily weight control;

- athlete's self-esteem journal;
- assesment of physical well-being by the coach (training tests);

- analysis of the peripheral blood indicators (whenever possible).

Table 2 presents the recommended method for the diagnosis and control of the climatic and geographical adaptation in athletes taking into account both non-specific and specific adaptation criteria.

It is recommended to use fitness trackers, which track sleep quality and are capable of tracking such parameters as total sleep time, total time in bed, sleep efficiency (sleep phases analysis), and time to the first wake-up, for the mobile diagnosis of a number of specific adaptation criteria, namely the normal sleep restoration.

In addition to the analysis of sleep, fitness trackers allow the athlete to pursue a strategy of maintaining the "domestic routine" after moving to the competition venue by crossing more that three time zones.

\section{CONCLUSION}

In order to minimize the effects of negative factors, resulting from the athletes' climatic and geographical adaptation, special attention should be paid to the following aspects: preliminary assessment of the althlete's health and performance when taking part in the competitions; in-depth study of physiological and hygienic features of adaptation in athletes from various 
Table 2. Method for diagnosis and control of climatic and geographical adaptation in athletes

\begin{tabular}{|c|c|c|c|c|c|c|c|c|c|c|c|c|c|c|}
\hline \multirow{2}{*}{ Diagnostic methods } & \multicolumn{14}{|c|}{ Day after the journey } \\
\hline & 1 & 2 & 3 & 4 & 5 & 6 & 7 & 8 & 9 & 10 & 11 & 12 & 13 & 14 \\
\hline $\begin{array}{l}\text { Supervision of the sport physician } \\
\text { or coach }\end{array}$ & +++ & +++ & +++ & +++ & +++ & +++ & +++ & +++ & +++ & +++ & +++ & +++ & +++ & +++ \\
\hline Heart rate variability & +++ & +++ & +++ & +++ & +++ & +++ & +++ & - & - & - & - & - & - & - \\
\hline WAM questionnaire & +++ & +++ & +++ & +++ & +++ & +++ & +++ & - & - & - & - & - & - & - \\
\hline Weight control & +++ & +++ & +++ & +++ & +++ & +++ & +++ & - & - & - & - & - & - & - \\
\hline Athlete's self-esteem journal & +++ & +++ & +++ & +++ & +++ & +++ & +++ & +++ & +++ & +++ & +++ & +++ & +++ & +++ \\
\hline $\begin{array}{l}\text { Monitoring the dynamic changes } \\
\text { in physical condition }\end{array}$ & +++ & +++ & +++ & +++ & +++ & +++ & +++ & - & - & - & - & - & - & - \\
\hline $\begin{array}{l}\text { Analysis of the peripheral blood } \\
\text { indicators }\end{array}$ & + & + & + & + & + & + & + & - & - & - & - & - & - & - \\
\hline Fitness tracker or smartwatches & +++ & +++ & +++ & +++ & +++ & +++ & +++ & +++ & +++ & +++ & +++ & +++ & +++ & +++ \\
\hline
\end{tabular}

Note: +++ — strongly recommended; ++ — recommended; + — at the discretion of the athlete, the coach or the team physician; - — avoid using.

sports at the various stages of training and competitive activity; continuous pursuit and improvement of the means for the athlete's performance optimization, particularly in the context of long-distance flights and extreme climatic conditions; developing the new methods for adjustment and improvement of the athlete's heat tolerance; accelerated adaptation to the adverse effects of the chronobiological rhythms desynchronization.

\section{References}

1. Samojlov AS, Petrova W. Aktual'nye voprosy adaptacii sportsmenov k Rio-de-Zhanejro. Sportivnaja medicina: nauka i praktika. 2016; 4: 27-28. Russian.

2. Dvornikov MV, Bragin MA, Kish AA, Petrova VV. Metodika integral'noj ocenki teplovogo sostojanija sportsmena $\vee$ uslovijah vysokih temperatur. Medicinskaja nauka i obrazovanie Urala. 2017; 4 (92): 118-22. Russian.

3. Aljakrinskij BS, Stepanova SI. Po zakonu ritma. M.: Nauka, 1985; s. 90-109. Russian.

4. Ataliev YaA, Ovezgeldyeva GO, Grigoryan AG, Kulieva AM. Vlijanie vysokoj vneshnej temperatury na fizicheskuju rabotosposobnost' sportsmena. Pedagogiko-psihologicheskie i mediko-biologicheskie problemy fizicheskoj kul'tury i sporta. 2009; 3: 35-39. Russian.

5. Bagmet KM. Optimizacija podgotovki basketbolistov v razlichnyh klimaticheskih uslovijah. Moskva, 2001; 286 s. Russian.

6. Baevskij RM. Problema prognozirovanija sostojanija organizma v processe ego adaptacii k razlichnym vozdejstvijam. V knige: Nervnye i jendokrinnye mehanizmy stressa. Kishinev: Shtinica, 1980; s. 30-61. Russian.

7. Razinkin SM, Berzin IA, Petrova WV, Samojlov AS, Fomkin PA

\section{Литература}

1. Самойлов А. С., Петрова В. В. Актуальные вопросы адаптации спортсменов к Рио-де-Жанейро. Спортивная медицина: наука и практика. 2016; 4: 27-28.

2. Дворников М. В., Брагин М. А., Киш А. А., Петрова В. В. Методика интегральной оценки теплового состояния спортсмена в условиях высоких температур. Медицинская наука и образование Урала. 2017; 4 (92): 118-22.

3. Алякринский Б. С., Степанова С. И. По закону ритма. М.: Наука, 1985; с. 90-109.

4. Аталиев Я. А., Овезгельдыева Г. О., Григорьян А. Г., Кулиева А. М. Влияние высокой внешней температуры на физическую работоспособность спортсмена. Педагогикопсихологические и медико-биологические проблемы физической культуры и спорта. 2009; 3: 35-39.

5. Багмет К. М. Оптимизация подготовки баскетболистов в
The use of the recommended adaptation strategies together with the diagnosis and control methods, allowing one to monitor both non-specific and specific adaptation criteria, would make it possible to not to miss disadaptation in athletes, as well as to properly plan the adjustment and adjust the pathological manifestations, resulting from the impact of the negative climatic and geographical factors.
Fiziologo-gigienicheskoe obosnovanie optimizacii processov adaptacii sportsmenov k uslovijam Rio-de-Zhanejro (obzor literatury). Medicina jekstremal'nyh situacii. 2015; 4: 22-32. Russian.

8. Razinkin SM, Samojlov AS, Korolev AD, Nazarjan SE. Ocenka jeffektivnosti metodiki korrekcii psihojemocional'nogo sostojanija sportsmenov sbornoj Rossii. Medicina jekstremal'nyh situacij. 2015; 4 (54): 62-67. Russian.

9. Agadzhanyan NA. Shabatura NN. Bioritmy, sport, zdorov'e. Fizkul'tura i sport. 1989; 208 s. Russian.

10. Lenc NA. Podgotovka i sorevnovatel'naja dejatel'nost' sportsmenov vysshej kvalifikacii $\vee$ razlichnyh prirodnogeograficheskih uslovijah. Moskva, 2004; 368 s.

11. Chvyrev VG, Azhaev AN, Novozhilov GN. Teplovoj stress. M.: Medicina, 2000; 296 s. Russian.

12. Jashina ER, Abramova TF, Nikitina TM, i dr. Osobennosti hronobiologicheskoj i klimatogeograficheskoj adaptacii vysokokvalificirovannyh sportsmenov k uslovijam Rio-de-Zhanejro s uchetom osobennostej vidov sporta. M.: Izdatel'stvo 000 "NIPKC Voshod-A", 2016; 512 s. Russian.

различных климатических условиях. Москва, 2001. 286 с.

6. Баевский Р. М. Проблема прогнозирования состояния организма в процессе его адаптации к различным воздействиям. В книге: Нервные и эндокринные механизмы стресса. Кишинев: Штиница, 1980; с. 30-61.

7. Разинкин С. М., Берзин И. А., Петрова В. В., Самойлов А. С., Фомкин П. А. Физиолого-гигиеническое обоснование оптимизации процессов адаптации спортсменов к условиям Рио-де-Жанейро (обзор литературы). Медицина экстремальных ситуаций. 2015; 4: 22-32.

8. Разинкин С. М., Самойлов А. С., Королев А. Д., Назарян С. Е. Оценка эффективности методики коррекции психоэмоционального состояния спортсменов сборной России. Медицина экстремальных ситуаций. 2015; 4 (54): 62-67. 
9. Агаджанян Н. А. Шабатура Н. Н. Биоритмы, спорт, здоровье. Физкультура и спорт. 1989; 208 с.

10. Ленц Н. А. Подготовка и соревновательная деятельность спортсменов высшей квалификации в различных природногеографических условиях. Москва, 2004; 368 с.

11. Чвырев В. Г., Ажаев А. Н., Новожилов Г. Н. Тепловой стресс.
М.: Медицина, 2000; 296 с.

12. Яшина Е. Р., Абрамова Т. Ф., Никитина Т. М. и др. Особенности хронобиологической и климатогеографической адаптации высококвалифицированных спортсменов к условиям Риоде-Жанейро с учетом особенностей видов спорта. М.: Издательство ООО «НИПКЦ Восход-А», 2016; 512 с. 